History of Political Thought 35.4 (2014): 656-682

\title{
Walter Chatton on Dominium
}

\author{
Jonathan Robinson ${ }^{1,2}$
}

\section{Introduction}

Walter Chatton (ca.1290-1343/4), is best remembered today, when he is remembered at all, as an English Franciscan theologian whose forceful criticism of certain aspects of William of Ockham's (ca. 1285-1347) philosophical views forced the latter to re-think his earlier position. ${ }^{3}$ Although there is no evidence that this was the case with respect to Ockham's political views, this does not

1 School of Canon Law, The Catholic University of America, 620 Michigan Avenue, NE, Washington, DC 20064. jonwrobinson@gmail.com

2 The research for this paper was made possible in part thanks to a post-doctoral fellowship from the Social Sciences and Humanities Research Council of Canada. I am also grateful to Ryan Greenwood and the anonymous reviewers for History of Political Thought, whose perceptive comments encouraged me to reflect upon Chatton anew.

3 Rondo Keele, 'Walter Chatton', in The Stanford Encyclopedia of Philosophy, ed. Edward N. Zalta, Fall 2012 edition (2012), is the most recent survey of his life and thought; the comments in William J. Courtenay, Adam Wodeham: An Introduction to His Life and Writings, Studies in Medieval and Reformation Thought 21 (Leiden, 1978), pp. 66-74, and Gedeon Gál and Stephen F. Brown, eds., Guillelmi de Ockham Opera philosophica, vol. 1: Summa logicae (St. Bonaventure, NY, 1974), pp. $47^{*}-55^{*}(=\mathrm{OPh} 1)$, are still valuable. Most of Chatton's philosophical writings have now been edited; they are included in the following list of abbreviations:

$A_{C C}^{2} \quad$ John XXII, Ad conditorem canonum, redactio secunda, in Jacqueline Tarrant, ed., Extravagantes Iohannis XXII, Monumenta iuris canonici, Series B: Corpus collectionum 6 (Rome, 1983)

Collatio Joseph C. Wey, ed., Walter Chatton: Reportatio et Lectura super Sententias: Collatio ad Librum Primum et Prologus, Studies and Texts 90 (Toronto, 1989) 
mean Chatton's contribution to the poverty controversy is without interest. In fact, although it is sometimes complained that Chatton was a better critic than constructive system-builder, we cannot say this of his defense of Franciscan poverty. His attempt to reconcile the recent pronouncements of an increasingly critical Pope John XXII from the early 1320 s shows a good deal of novelty, both in terms of how he repositions the axioms of the debate and in the conclusions he draws from them.

Chatton evidently thought the question of Franciscan poverty was an important one, for he wrote about it three times following the publication of $A d$ conditorem canonum (first version dates from 8 December 1322; second from about a month later). ${ }^{4}$ We have a reportatio of the sixteenth question of the third book of his Sentences commentary; the treatise De paupertate evangelica; and what is probably a re-elaboration in quaestio form (itself likely a reportatio). The three texts are closely related, but distinct. Decima Douie edited the treatise and the quaestio together even though they are different enough that she could not collate the two texts. Instead she marked in the texts and in the notes where there was significant agreement or disagreement between the two. This means one has an edition of the treatise that is 'confirmed' where possible by the subsequent quaestio.

The following considerations allow us some precision in terms of the relevant dating of the different texts. It is thought that Chatton delivered his Reportatio

\footnotetext{
De paupertate

Tractatus de paupertate evangelica editus a fratre Waltero de Chatton' Oxon', in Decima L. Douie, 'Three Treatises on Evangelical Poverty by Fr. Richard Conyngton, Fr. Walter Chatton and an Anonymous from MS. V III 18 in Bishop Cosin's Library, Durham', Ar-chi-vum franciscanum historicum, XXV (1932), pp. 36-58, 210-240, pp. 36-58, 210-40

Lectura Joseph C. Wey and Girard J. Etzkorn, eds., Walter Chatton: Lectura super Sententias, 3 vols., Studies and Texts 156, 158, and 164 (Toronto, 2007-2009)

OP H. S. Offler et al., eds., Guillemi de Ockham opera politica, 9 (projected) vols. (Manchester \& Oxford, 1956-)

Reportatio

Joseph C. Wey and Girard J. Etzkorn, eds., Walter Chatton: Reportatio super Sententias, 4 vols., Studies and Texts 141-142, 148-149 (Toronto, 2002-2005)
}

Except for the De paupertate, which is cited by page number alone, I cite the texts in order of decreasing generality, followed by a page reference in parentheses.

4 Jürgen Miethke, Ockhams Weg zur Sozialphilosophie (Berlin, 1969), p. 388. 
on the Sentences between 1321 and $1323 .{ }^{5}$ Since the Reportatio quotes directly from and refers to arguments that are only found in the redacted version of Ad conditorem, ${ }^{6}$ yet makes no mention of Cum inter nonnullos (12 November 1323), he must have lectured on the third book of the Sentences in the spring of 1323 at the earliest, but probably not much later than November of the same year. The re-elaboration of the question in the Reportatio in the form of the treatise likewise probably came before the contents of Cum inter became known in England. ${ }^{7}$ Although we cannot be certain that the treatise was written before he knew the second bull, the fact that the quaestio does contain a reference to Cum inter does suggest that only the quaestio was written after November 1323. ${ }^{8}$ Since, finally, none of the texts contain a reference to Quia quorundam mentes (10 November 1324), the quaestio itself must have terminus ante quem of about November 1324 .

In addition to the tight time frame in which the different texts were composed, they likewise betray a very close correspondence in terms of content. ${ }^{9}$ Thus,

$5 \quad$ Keele, 'Walter Chatton', § 1; Rondo Keele, 'Oxford Quodlibeta from Ockham to Holcot', in Theological Quodlibeta in the Middle Ages: The Fourteenth Century, ed. Christopher Schabel, Brill Companions to the Christian Tradition 7 (Leiden, 2007), pp. 651-692, pp. 667-8.

6 Cf. Reportatio 3.16.1.55, 58, 60, 62, 64, 69, 71, 75, 77 (4:155-60), with $A C C^{2}$ 90-93, 132-138 (236, 240), 139-143 (240), 144-150 (240-1), 158-167 (242-3), 168-187 (243-5), 188-191 (245), 193-208 (245-6), 229-238 (248-9), and 239-286 (249-53). Most of these passages are completely missing in the first redaction of the bull. For convenience, it may be best to consult the comparison of the two bulls, with both the Latin texts and English translation, available online: http://individual.utoronto.ca/jwrobinson. See also Decima L. Douie, 'Three Treatises on Evangelical Poverty by Fr. Richard Conyngton, Fr. Walter Chatton and an Anonymous from MS. V III 18 in Bishop Cosin's Library, Durham', Ar-chi-vum franciscanum historicum, XXIV-25 (1931-1932), pp. 341-369, 36-58, 210-240, p. 346.

7 Wey and Etzkorn, eds., Chatton: Reportatio, 4:xii, date the lectures of Reportatio III-IV to 1323-24, but the omission of any mention of Cum inter, would suggest a delivery before or early in 1324. Cf. William J. Courtenay, 'Ockham, Chatton and the London Studium: Observations on Recent Changes in Ockham's Biography', in Die Gegenwart Ockhams, ed. Wilhelm Vossenkuhl and Rolf Schönberger (Weiheim, 1990), pp. 327-337, p. 330.

8 The manuscript Plut. 31 sin. 3 of the Biblioteca medicea laurenziana is available online at http://teca.bmlonline.it/, although the quality of the scan is rather poor. Thanks to the timely help of Ryan Greenwood I was able to consult it. The reference to the bull reads: 'Sed istud [dominium] Christus uel collegium [apostolorum] habuit secundum constitutionem Inter nonnullos' (fol. 189rb). See also Douie, 'Three Treatises', p. 220 note e, and Decima L. Douie, The Nature and the Effect of the Heresy of the Fraticelli, Historical Series 61 (Manchester, 1932), p. 204. Marino Damiata, Guglielmo d'Ockham: Povertà e potere, 2 vols. (Florence, 19781979), 1:345, has confused the relationship of the texts.

9 See Reportatio 4:357, for a list of correspondence between the De paupertate and the quaestio. 
although I think it was wrong to conflate a text which cited Cum inter with another that did not, because the three texts articulate a common and consistent point of view, we can provide a synchronic account of Chatton's thoughts about Franciscan poverty, at least from this period of his life. ${ }^{10}$ Before turning to Chatton, however, a brief word needs to be said about the state of the order around the time he wrote his texts in the 1320 .

\section{The Franciscan Order during the Reign of John XXII}

As is well-known, the mendicant poverty controversy reached a fevered pitch during the reign of Pope John XXII (r. 1316-1334). ${ }^{11}$ In some ways it has often been seen as a continental affair. A good example of this is perhaps Ockham's own account of how he finally became involved in the dispute. The document in question dates to 1334, that is, well after Ockham had fled Avignon under pain of excommunication because he was terrified by the prospect that the world's spiritual leader had become a heretic. Some caution, then, is merited when we read in his highly polemical Epistola ad fratres minores that,

You know, and all Christians know, that I sat around in Avignon for nearly four whole years before I came to realize that the one presiding there had incurred heretical depravity. For, not desiring to believe easily that a person established in so important an office would stipulate that heresies must be held, I cared neither to read nor to hold his heretical constitutions. ${ }^{12}$

As is well known, thanks to Michael of Cesena's initial urging, Ockham did become a trenchant and vociferous opponent of Pope John XXII and his successors. If, however, we can accept that Ockham was initially unwilling to find out how

10 Since he spent his last ten years or so in Avignon, it is generally assumed that at the very least he stopped defending his earlier views on Franciscan poverty vocally. See Douie, Heresy of the Fraticelli, p. 206, and Miethke, Ockhams Weg, p. 391.

11 See now my Jonathan Robinson, William of Ockham's Early Theory of Property Rights in Context, Studies in Medieval and Reformation Traditions 166 (Leiden, 2012), and 'Property Rights in the Shift from "Community" to "Michaelist", Rivista internazionale di diritto comune, XXII (2011), pp. 141-181, which contain ample recent bibliography. One recent omission, however, was Roberto Lambertini, 'Letters and Politics: Gerald Odonis vs. Francis of Marchia', Vivarium, XLVII.2 (2009), pp. 364-373.

12 Epistola (OP 3:6.9-14): 'Noveritis itaque (et cuncti noverint Christiani), quod fere quattuor annis integris in Avinione mansi, antequam cognoscerem praesidentem ibidem pravitatem haereticam incurrisse. Quia nolens leviter credere quod persona in tanto officio constituta haereses definiret esse tenendas, constitutiones haereticales ipsius nec legere nec habere curavi.' 
what heresies the pope was committing, which seems plausible, the question of chronology becomes interesting. According to the admittedly biased author of the so-called Chronicle of Nicholas the Minorite, Michael arrived in Avignon on 1 December $1327 .{ }^{13}$ It is also commonly thought that Ockham arrived in Avignon in about the summer of 1324, and certainly no earlier than the second quarter of that year. ${ }^{14}$ Since, moreover, Ockham and the other Michaelists fled Avignon on 28 April 1328, in what might be termed a daring escape, ${ }^{15}$ the dates given just above would seem to imply that Ockham was aware of what the pope had been publishing while still in England. ${ }^{16}$ That is, had he been so inclined, he likely would have had the opportunity to learn of at least Ad conditorem canonum and

13 Gedeon Gál and David Flood, eds., Nicolaus Minorita: Chronica. Documentation on Pope John XXII, Michael of Cesena and The Poverty of Christ with Summaries in English. A Source Book (St. Bonaventure, NY, 1996), p. 178. Patrick Nold, Pope fohn XXII and his Franciscan Cardinal: Bertrand de la Tour and the Apostolic Poverty Controversy (Oxford, 2003), is skeptical of what we may safely learn from the carefully compiled and strung-together narrative this chronicle comprises. See also Patrick Nold, 'Two Views of John XXII as a Heretical Pope', in Defenders and Critics of Franciscan Life: Essays in Honor of John V. Fleming, ed. Michael F. Cusato and Guy Geltner, The Medieval Franciscans 6 (Leiden, 2009), pp. 139-158.

14 William J. Courtenay, 'The Academic and Intellectual Worlds of Ockham', in The Cambridge Campanion to Ockham, ed. Paul Vincent Spade (Cambridge, 1999), pp. 17-30, p. 24. See also Léon Baudry, Guillaume d'Occam : Sa vie, ses œuvres, ses idées sociales et politiques. I. L'homme et les œuvres, Études de philosophie médiévale 39 (Paris, 1950), pp. 96-116; Girard J. Etzkorn, 'Ockham at a Provincial Chapter: 1323. A Prelude to Avignon', Ar-chi-vum franciscanum historicum, LXXXIII (1990), pp. 557-567; Girard J. Etzkorn, 'Ockham at Avignon: His Response to Critics', Franciscan Studies, LIX (2001), pp. 9-19; and Francis E. Kelley, 'Ockham: Avignon, Before and After', in From Ockham to Wyclif, ed. Anne Hudson and Michael Wilks, Studies in Church History, Subsidia 5 (Oxford, 1987), pp. 1-18. George Knysh, 'Biographical Rectifications Concerning Ockham's Avignon Period', Franciscan Studies, XLVI (1986), pp. 61-91, offered an alternative narrative, but it has not received much approbation; see in particular Courtenay, 'Ockham, Chatton and the London Studium', and Jürgen Miethke, 'Ockham-Perspectiven oder Entführung in eine falsche Richtung? Eine Polemik gegen eine neuere Publikation zu Ockhams Biographie', Mittellateinisches Jahrbuch, XXIX (1994), pp. 61-82.

15 Cf. Jürgen Miethke, 'Dominium, ius und lex in der politischen Theorie Wilhelms von Ockham', in Lex und Ius: Beiträge zur Grundlegung des Rechts in der Philosophie des Mittelalters und der Frühen Neuzeit, ed. Alexander Fidora, Matthias Lutz-Bachmann, and Andreas Wagner, Politische Philosophie und Rechtstheorie des Mittelalters und der Neuzeit, Texte und Untersuchungen II.1 (Stuttgart-Bad Cannstatt, 2010), pp. 241-269, p. 244; Eva Luise Wittneben, Bonagratia von Bergamo: Franziskanerjurist und Wortführer seines Ordens im Streit mit Papst fohannes XXII, Studies in Medieval and Reformation Thought 90 (Leiden, 2003), pp. $285^{-6 .}$

16 Cf. Kelley, 'Avignon, Before and After', p. 9 n. 30. 
Cum inter (12 November 1323), if not Quia quorundam mentes (10 November 1324). If we can believe him, however, Ockham had not been so inclined.

Yet, it is not at all clear that John's bulls about Franciscan poverty were received by other Franciscans with the same degree of insouciance as they were by Ockham. England in the early fourteenth century does not seem to have been a hotbed of Franciscan dissent the way it was in Italy and southern France, but the pope's bulls were known in England. They were, for instance, 'earnestly discussed' among Franciscans at Cambridge. ${ }^{17}$ Similar activities doubtlessly took place in other friaries and studia in England, but it is hard to ascertain how grave most English friars found the pope's pronouncements.

Walter Chatton, however, who was probably in residence with William of Ockham in London from $1321-23,{ }^{18}$ was concerned about the publication of $A d$ conditorem canonum, and he wrote his responses quickly enough that Ockham could have learned the import of the bull. If the tentative dates of composition outlined above are correct, Ockham had about a year where he could have learned of Chatton's views on Franciscan poverty (spring 1323 to the following spring). Yet, Ockham's own writings on poverty betrays no familiarity with Chatton's arguments or conclusions, although in a few places scholars have noted points where he anticipated some of Ockham's conclusions. ${ }^{19}$

There are, nonetheless, points of commonality with the Franciscan tradition. It is in this sense that we can discern some of the common intuitions fourteenthcentury Franciscans had regarding property rights. But Chatton was neither a Michaelist avant la lettre, nor any sort of 'Spiritual Franciscan' concerned more with the quality of use than the absence of proprietary lordship, nor did he, finally, merely wish to bend to Pope John XXII's interpretation of Franciscan poverty. Bend he did in the end, but not without serious reservations. ${ }^{20}$ In these earlier writings, he tried to reconcile a 'plain' understanding of dominium in a larger framework of the manifold (and usually specialist) meanings of dominium with the pope's own pronouncements. In so doing, Chatton provided a sophist-

John Moorman, The Grey Friars in Cambridge, 1225-1538 (Cambridge, 1952), pp. 95-8.

18 Etzkorn, 'Ockham at a Provincial Chapter', p. 559 n. 7. Courtenay, 'Ockham, Chatton and the London Studium', has stressed that Oxford cannot be ruled out entirely as the locus of the two friars' activities during these years.

19 Cf. Miethke, Ockhams Weg, p. 391; Andrea Tabarroni, Paupertas Christi et apostolorum: L'ideale francescano in discussione (1322-1324), Nuovi studi storici 5 (Rome, 1990), p. 95.

20 Ulrich Horst, Evangelische Armut und päpstliches Lehramt: Minoritentheologen im Konflikt mit Papst fohannes XXII. (1316-34), Münchener Kirchenhistorische Studien 8 (Stuttgart, 1996), p. 45 n. 65. 
icated account by medieval standards of the powers associated with proprietary lordship. When it came to evangelical poverty and property, the Franciscan tradition was rich indeed, and not reducible to one or two basic positions.

\section{Chatton on Ius}

As the debates of the fourteenth century tended to turn on the various meanings an author assigned to the terms ius, dominium, and usus, I shall analyze Chatton's views in the same way. However, we should note at the outset that Chatton makes much of the fact that '[he] does not intend here to use the terminology of canon or civil law', but rather 'to use the manner of speaking according to the understanding that men commonly have in the Church, who are not trained in the terminology of this or that law (ius), whether they are simple people, or are more or less instructed in sacred scripture'. ${ }^{21}$ As we shall see, it proved impossible to wholly avoid legal language and concepts, but, to take Ockham as a point of comparison once again, it is true that his interpretation of many key terms owes little to the ius commune. On the one hand, Chatton can be read as taking a sly jab at the lawyers in the perennial dispute about the relative superiority of the faculties of law and theology. ${ }^{22}$ To be sure, we would probably look in vain for a medieval theologian or a lawyer who ranked his own scientia second in importance, but aside from any rhetorical purpose such a focus might be thought to have-including, for instance, cutting short any overly juridical definitions of use or lordship-there are relatively obvious philosophical reasons for keeping in view such 'non-technical' definitions. ${ }^{23}$

21 De paupertate, pp. 41-2; Reportatio 3.16.1.21 (4:145). The point is repeated often throughout Chatton's discussion. See Miethke, Ockhams Weg, p. 388; Tabarroni, Paupertas Christi, p. 91.

${ }^{22}$ For recent discussions of this topic, see Karl Shoemaker, 'When the Devil Went to Law School: Canon Law and Theology in the Fourteenth Century', in Crossing Boundaries at Medieval Universities, ed. Spencer E. Young, Education and Society in the Middle Ages and Renaissance 36 (Leiden, 2011), pp. 255-275, pp. 255-6, which includes substantial bibliography.

23 One might compare Ockham's rather different explanation for why one needs to determine when a term is being used literally or otherwise; see Summa logicae 1.77 (OPh 1:237): 'Et ideo multum est considerandum quando terminus et propositio accipitur de virtute sermonis et quando secundum usum loquentium vel secundum intentionem auctorum, et hoc quia vix invenitur aliquod vocabulum quin in diversis locis librorum philosophorum et Sanctorum et auctorum aequivoce accipiatur; et hoc penes aliquem modum aequivocationis. Et ideo volentes accipere semper vocabulum univoce et uno modo frequenter errant circa intentiones auctorum et inquisitionem veritatis, cum fere omnia vocabula aequivoce accipiantur.' An 
Chatton, like most philosophers, defended the view that knowledge had a role to play in evaluating the moral status of one's actions: ${ }^{24}$

If you ask whether he can wish to give to anyone what is his own without a practical syllogism, I say that it is so. If [you ask] whether you might hold that, in acting laudably, the manner of acting (processum) is 'right' without a practical syllogism, I say that it is not so.... In order to act in a praiseworthy manner, love and knowledge of the end is required beforehand. ${ }^{25}$

A practical syllogism, as Chatton explained elsewhere, is 'directive of our actions' $;{ }^{26}$ but it is formed from abstract thoughts (ex cognitionibus abstractivis). ${ }^{27}$ The point in all this is simply that one needs to know what one is doing in order to merit praise or blame for one's voluntary actions. Since adherence to and violations of a religious vow is a deeply ethical issue, Chatton insisted that giving up lordship was not merely an example of privation, which was commonly understood as being unable to contribute to perfection: it was rather a positive act of the will. ${ }^{28}$ There is thus good reason to insist on limiting the meanings of

example of a diversitas locutionis in his political writings can be seen with respect to the potentia dei controversy; see Opus nonaginta dierum (= OND) 95.375-437 (OP 2:725-7); cf. Contra Benedictum 3.3 (OP 3:231.30-234.25). Janet Coleman, 'Using, Not Owning-Duties, Not Rights: The Consequences of Some Franciscan Perspectives on Politics', in Defenders and Critics of Franciscan Life: Essays in Honor of John V. Fleming, ed. Michael F. Cusato and Guy Geltner, The Medieval Franciscans 6 (Leiden, 2009), pp. 65-84, p. 74; and Janet Coleman, 'The Relation between Ockham's Intuitive Cognition and his Political Science', in Théologie et droit dans la science politique de l'état moderne : actes de la table ronde organisée par l'École française de Rome avec le concours du CNRS, Rome, 12-14 novembre 1987 (Rome, 1991), pp. 71-88, pp. 78-9, has discussed the first and third of these passages respectively.

24 Almost nothing has been written about Chatton's ethical views, but see now Tobias Hoffmann, 'Walter Chatton on the Connection of the Virtues', Quaestio, VIII (2008), pp. 57-82, and Keele, 'Walter Chatton', § 4 .

25 Reportatio 3.33.4.11-12 (4:232-3): 'Si quaeris an iste possit velle dare cuilibet quod suum est sine syllogismo practico, dico quod sic. Si an sine syllogismo practico teneas processum rectum in laudabiliter agendo, dico quod non.... Sed ad laudabiliter agendum praeexigitur amor et notitia finis.' See also the comments in Collatio 6.3 and 7.2 (344.124-45.138 and 373.114-74.124).

26 Reportatio 1.35.2.37 (2:320-1): 'Primum non possunt [sc. Ockham] tenere, quia non possunt dicere quin et iste syllogismus et suae etiam praemissae sint practicae, eo quod [sunt] directivae actionum nostrarum "omne bonum est faciendum; ieiunare est bonum; igitur etc.", quia eo ipso quod propositiones istae et syllogismus sunt directivae actionum nostrarum, sunt practicae.' See also Collatio 7.1 (365.249-251), and Reportatio 3.18.1.20 (4:173).

27 Reportatio 1.1.3.23 (1:57): 'dixi enim prius syllogismum practicum formari ex cognitionibus abstractivis.'

28 Cf. De paupertate, pp. 41 and 240; Reportatio 3.16.1.11 (4:142). 
dominium to those that a religious would have implicitly understood when he made the vow. Technical, legal meanings of dominium were quite simply not part of the vocabulary of a 'simple cleric or layman' who has entered religion and experienced it for a year before making his vow. Such a person does not only not know the laws (iura), he does not even care about how it (ius) might be explicated. ${ }^{29}$ In fact, the order's General Constitutions repeatedly show just how simple and uncomplicated a friar's vow of poverty was. ${ }^{30}$

This attitude explains the scanty attention paid to the meaning(s) of ius in Chatton's texts, and the equally low profile of lex as well. Yet the two terms do not disappear from sight altogether. At one point, in his discussion about whether it can be proven by natural reason that people are bound to love God above all else, Chatton seems to off-handedly equate lex naturae, lex naturalis, and ius naturale, which he inaccurately quoted from the Decretum. ${ }^{31}$

Chatton evidently believed in the inviolability of ius naturale, for when he came to refuting Nicholas Trevet, a Dominican active in Oxford around the same time as Chatton, ${ }^{32}$ he implicitly agreed with this aspect of the argument. (His concern was the nature of dominium, to which we shall return.) Trevet had apparently claimed that 'lordship in common' belonged to a person by ius

29 Reportatio 3.16.1.21 (4:145).

30 The vow remained unchanged from at least the time of the Constitutiones narbonenses (1260) through the time under consideration. See Caesar Cenci and Roman George Mailleux, eds., Constitutiones generales ordinis fratrum minorum I (Saeculum XIII), Analecta franciscana (Nova Series. Documenta et studia 1) 13 (Grottaferrata, 2007), pp. 71, 112, 160, 289, and Caesar Cenci and Roman George Mailleux, eds., Constitutiones generales ordinis fratrum minorum II (Saeculum XIV/I), Analecta franciscana (Nova Series. Documenta et studia 2) 17 (Grottaferrata, 2010), pp. 62, 136-7, 223, 345; in each case the example text reads: 'Ego frater N. voveo et promitto Deo et beatae Mariae virgini et beato Francisco et omnibus sanctis et tibi, pater, toto tempore vitae meae servare regulam Fratrum Minorum, per dominum Honorium papam confirmatam, vivendo in obedientia, sine proprio et in castitate.'

31 Lectura 1.1.2.192 and 217 (1:79-86). Chatton's reference to Gratian-viz, 'in Decretis dist. 10 c. "Cum igitur in naturali iure" -is incorrect and thus stumped the editors, but is quite clearly a reference to the preceeding passage, D. 9 d.p.c. 11, which reads 'Cum ergo naturali iure' in Aemilius Friedberg, ed., Corpus iuris canonici, 2 vols., Editio lipsiensis secunda (Leipzig, 1959), Vol. 1, col. 18. Anyone familiar with Latin palaeography knows that the difference between ergo and igitur hardly matters a jot. Likewise, the preposition 'in' was probably a common variant. In one manuscript which I have at my disposal, Gratian's dictum (d.p.c. 11) begins 'Cum ergo in naturali iure' (Munich, Bayerische Staatsbibliothek $\mathrm{Clm} 28161$, fol. 12b). The later Editio romana (1582) likewise includes the preposition.

32 Courtenay, 'Academic and Intellectual Worlds', p. 21; and Schools and Scholars in FourteenthCentury England (Princeton, 1987), pp. 175-82. 
naturale. ${ }^{33}$ In the De paupertate, Chatton's issue was not with the lordship itself but with the imprecise way the phrase 'in communi' was being used; was it, he wondered, the whole world or merely a special 'college' such as a convent; and, in fact, why wouldn't this argument apply to an individual just as well as a community? ${ }^{34}$

Elsewhere, Chatton showed just as little concern for ius in a more recognizably 'subjective' form, namely in the passages in which he treated of the so-called right of using. Although the De paupertate subjects Ad conditorem canonum to a fairly close reading, Chatton did not care much to discuss what is meant by ius utendi, perhaps because he thought it smacked too much of the courtroom. Chatton quoted from the bull where it is argued that neither use nor the right of using can be had for consumables since ownership perpetually without use must be considered useless. ${ }^{35}$ The Reportatio does not answer this objection by explaining what a ius utendi is. Chatton merely responded that this argument would militate against the personal poverty of all religious, 'which is not conceded', and that such an argument does not seem to pertain only to consumables. ${ }^{36}$ Both of these are Michaelist/Franciscan commonplaces: wherever possible, they tried to point out that the pope's arguments about consumables-were they true-would render all members of religious orders individual property-holders. ${ }^{37}$ The De paupertate offers a longer answer to this point, but it casts the question of rights of using consumables in the context

33 De paupertate, p. 238: ' $4^{\circ}$ arguunt sic. Homo non potest privari iure naturali; sed habere dominium in communi convenit sibi ex iure naturali, quia dictum est homini, Genesis $1^{\circ}$ : Dominamini piscibus maris [Gen. 1:28] etc.'

34 De paupertate, p. 238; Reportatio 3.16.1.57, 111-112 (4:155-6, 165-6). The latter reference has the more direct argument: 'Idem arguo ego de privare se iure proprio. Nam quid intelligunt per communitatem?' I have analyzed contemporary Franciscan views on corporate poverty in Robinson, Ockham's Early Theory, pp. 255-84.

35 De paupertate, p. 219: 'Quia in talibus rebus consumptibilibus usu nec usus qui est servitus personalis, nec ius utendi quod non est servitus sed mere ius personale, nec etiam ipse actus utendi sine iure aliquo possunt in rebus talibus constitui sine proprietate, quia quilibet praemissorum exigit, quod ex re ipsa, salva rei substantia, possit ipsi habenti utilitas aliqua provenire, eo quod proprietas reputatur inutilis a qua perpetuus usus abscedit; istud autem de rebus consumptibilibus usu nequit reperiri.' The italicized words are from $A C C^{2} 132-137$ (240). Reportatio 3.16.1.55 (4:155) is similar, though surely we must read servitus for servatum!

36 Reportatio 3.16.1.56 (4:155).

37 Cf., e.g., De paupertate, p. 224: 'Quia quilibet religiosus sit totalis dominus et immediatus rerum illarum, quas consumit.' Among Michaelist texts, see Appellatio maior (= App. maior), ed. Gál and Flood (above, n. 13) 228, 248, 262, 335, and 361, and Appellatio monacensis, ed. Gál and Flood, 672, 823-24, and OND 9.649-687 (OP 2:397-9). 
of whether 'the lord Pope reserved to the Roman Church the dominium of one egg, one curd of cheese, one crust of bread, or other such things of which the brothers have the use'. ${ }^{38}$

There are two different places where Chatton seems to have assimilated the ius utendi to being a type of dominium or at least potestas. The first arises in reference to the pope's claim that any use without a right of using must be unjust. ${ }^{39}$ Chatton half-agreed: the argument is good for a 'licit power of using', but why does it work for the power of claiming in court, conserving beyond necessity, or exchanging ${ }^{40}$-that is, the three characteristics which, for Chatton, make up one important meaning of dominium.

The second passage is the longest discussion by Chatton about ius utendi. It comes in his response to John's point that any just use requires a right of using. ${ }^{41}$ Unlike other defences of Franciscan poverty, Chatton did not reject the argument outright. His response is therefore a little surprising. First, he explained that the pope's argument does not work for the ius utendi that the brothers have abdicated in their vow. So far, Chatton has kept to a common Franciscan point of view. But he then added that it also has nothing to do with the ius that the pope has (if he should reserve such a ius utendi on the consent of the friars). Rather, it is an argument about the ius utendi that refers to the power of licitly consuming a thing. Otherwise, he continued, the argument would prove that Christ (and indeed other religious) had exclusive human dominium-which is a conclusion he took to be patently absurd..$^{2}$ In fact, Chatton concluded, what

38 De paupertate, p. 219: 'Quia nullus diceret, quod dominus Papa reservaverit Romanae Ecclesiae dominium unius ovi, unius casei vel unius frusti panis vel talium rerum quarum fratres habent usum' ; cf. Reportatio 3.16.1.54-55 (4:154-5): 'Dico quod aequivocat de dominio.' See $A C C^{2}$ 90-93 (236).

$39 A C C^{2} 188-192$ (245). John was particularly fond of this argument, and repeated it in subsequent bulls; see Robinson, Ockham's Early Theory, pp. 57-61, for a fuller discussion.

$4^{0}$ Reportatio 3.16.1.70 (4:158): 'Istud argumentum est bonum de licita potestate utendi, quia clarum est quod sine illa iniuste uteretur. Sed quid hoc ad potestatem iudicialiter vindicandi, conservandi ultra necessitatem et commutandi?'

$41 \quad$ ACC 2 199-203 (246): 'Quantum enim ad usum facti absque omni iure utendi simplicem attinet, nulla rerum ad fratres differencia est censenda. Sic enim uti de facto possunt prohibitis et permissis. Quare premissa rerum distinccio ad illum usum facti pocius est referenda, pro quo ipsis competit fratribus ius utendi.' The italicized portions (or their equivalent) can be found in De paupertate, p. 225.

$4^{2}$ De paupertate, p. 225: 'Ista deductio non est contra praedictam, sicut patet ad V argumentum et ad VII, quia non currit de iure utendi, sumendo ius utendi quomodo fratres ius utendi abdicant in voto suo; nec etiam quomodo dominus Papa ius habet, si tale ius utendi ex assensu fratrum sibi reservet, quale superius est descriptum. Sed procedit sumendo ius 
is really being spoken about is proprietas and dominium, which is there being taken for the power of licitly consuming a thing. ${ }^{43}$

It thus seems clear that Chatton mostly avoided worrying about ius, and when he did, he connected it to dominium. That is, when the friars said they had vowed to live without any ius utendi, they meant that they had abdicated any sort of proprietary mastery over the things they used. By their vow, friars gave up any personally-determined power to licitly consume a thing. Obviously, friars did use and consume things; what Chatton meant was that authorization to use had to come from someone else, not the friar himself. This is analogous to the situation of the apostles. Christ had neither ius nor dominium, and he did not wish the apostles to have any either, even in common. All he permitted them-and established by law-was the accepting of the things necessary for life, and that they not be concerned about any such thing, nor contend in court for it. ${ }^{44}$

\section{Chatton on Dominium}

Since our focus is on the theory of property rights itself, and not on what kind of property rights Christ did or did not have, I shall refrain from worrying about the question of dominium in the early Church except insofar as it sheds light on the theory of property itself. But with this comes one caveat: it is assumed throughout that any 'historical' state of affairs that Chatton describes about features of property rights from earlier periods are just as possible now as they were then, unless he explicitly says that that is not the case.

Chatton started the De paupertate by distinguishing between two major types of dominium, divine and human, with the express goal of showing that Christ

utendi, pro potestate licite consumendi rem. Aliter enim aeque probaret, quod Christus habuit dominium proprium humanum; aliter etiam esset contra omnes religiosos, ut dictum est.'

43 De paupertate, p. 225: 'Ideo videtur dicendum secundum praedicta, quod ibi sumitur proprietas et dominium pro potestate licite consumendi rem; et sic bene procedit, non autem sumendo dominium aliis modis.'

44 De paupertate, p. 38: 'Ibi patere potest volenti nolenti advertere, quod Chrysostomus asserit, quod nec Christus habuit, nec Apostolos habere voluit aliquid sui iuris vel dominii etiam in communi, qui, secundum ipsum, et transeuntibus et residentibus solum hoc permisit et lege instituit: ab aliis accipere necessaria vitae, nec de aliquo tali sollicitos esse, sed in solo Deo fiduciam habere sine pluri. Etiam tollenti tunicam iubet Christus relinquere pallium, nec pro aliquo tali in iudicio contendere.' He argued that Bede meant the same thing in the following paragraph. 
practiced the highest poverty while in possession of divine lordship, but without the human variety. Dominium might be considered divine or human either in terms of its source or in terms of who possesses it. Chatton, unfortunately, never made it clear in which sense he meant the distinction, although it is clear that he was only interested in the varieties humans might possess, regardless of their source. ${ }^{45}$ In fact, having made this basic distinction, Chatton thereafter ignored 'divine' lordship and presented a complex picture of human lordship. The one characteristic that all forms of human lordship seem to share is that, whatever the type, human dominium is renounceable. In an interesting twist, Chatton explained the passage from Genesis, 'exercise lordship over the fish of the sea' $(1: 28)$ in terms of its final cause. ${ }^{46}$ On this, he differed substantially from the emerging and contemporary Michaelist perspective. ${ }^{47}$ According to Chatton, the passage should be understood to mean we were born to exercise lordship over these creations, 'not that anyone is actually (actu) a lord of some part of the world, but only that everyone has been born to exercise lordship'. Lest that sound exactly like natural lordship, he added: 'So each and every religious, apostle, and even Christ, had been born fit to have human dominium; but each one did not have it: this was because each one freely wished to lack all lordship on account of God. ${ }^{38}$ In other words, although we are born to dominate, as it

45 De paupertate, p. 36; cf. Reportatio 3.16.1.7 (4:141).

$4^{6}$ This passage is perhaps most famous in this debate because of the central role it played in John's thinking about dominium and the naturalness of property. See Quia vir reprobus, ed. Gál and Flood (above, n. 13), pp. 569-70; Jürgen Miethke, 'Paradiesischer Zustand Apostolisches Zeitalter - Franziskanische Armut: Religiöses Selbstverständnis, Zeitkritik und Gesellschaftstheorie im 14. Jahrhundert', in Vita religiosa im Mittelalter. Festschrift für Kaspar Elm zum 7o. Geburtstag, ed. Franz J. Felten and Nikolas Jasprert (Berlin, 1999), pp. 503-532, provided an excellent survey of the topic.

47 I have examined this topic extensively in Robinson, 'Property Rights', pp. 146-57 and 169-74, and Robinson, Ockham's Early Theory, pp. 120-74. As one reviewer pointed out, this difference raises interesting questions about whether different sorts of 'foundational' texts were in use in different studia. Future research will need to consult Bert Roest, $A$ History of Franciscan Education (c. 1210-1517), Education and Society in the Middle Ages and Renaissance 11 (Leiden, 2000), pp. 197-234; Bert Roest, Franciscan Literature of Religious Instruction Before the Council of Trent, Studies in the History of Christian Traditions 117 (Leiden, 2004), 120-68 and 206-221; and Neslihan Şenocak, The Poor and the Perfect: The Rise of Learning in the Franciscan Order, 1209-1310 (Ithaca, 2012), pp. 189-242.

$4^{8}$ De paupertate, p. 239: 'Dico ergo, quod illud verbum Gen. intelligitur sic: Domininamini id est: sitis nati dominari eis; non quod actu quilibet sit dominus alicuius partis mundi, sed tantum quod quilibet sit natus dominari. Ita quilibet religiosorum et Apostolorum, etiam Christus, aptus natus fuisset habuisse dominium humanum. Quod autem non habuerit, hoc fuit, quia propter Deum libere tali dominio voluit carere.' 
were, we are not obligated to exercise this faculty. If one wonders how one could live without any (human) lordship, Chatton suggested three ways: by labouring, by begging, or through the free gift of alms. ${ }^{49}$ Lordship itself can be considered superfluous since one can get by on use alone..$^{50}$

As for what lordship consists of, Chatton provided a number of different answers. There is, first of all, the issue of what dominium means in terms of the Franciscan vow. This is the sense of the term that we must usually bear in mind with regard to questions of Franciscan poverty, which itself requires a consideration of what poverty means in this context. For Chatton, when speaking about poverty undertaken out of love for God, one desires to lack three things:

P1. to lack lordship and use of superfluous things;

P2. to lack lordship of things one still must use to stay alive; and

P3. to lack superfluous use of things necessary to stay alive. ${ }^{11}$

In other words, Chatton thought a Franciscan desired to lack all but the nonsuperfluous use of necessary things. He came about as close as a friar could get to defending the Olivian notion of usus pauper as one could get without making it an explicit feature of the vow of poverty. Two other points are apparent. First, the two categories of things one must consider are 'necessary' and 'unnecessary' for the prolongation of human life..$^{22}$ Second, lordship must be completely abdicated, while use cannot be.

49 De paupertate, p. 56.

5o De paupertate, p. 48: 'aut hoc arguo, quia dominium proprium superfluit sibi pro necessitate praesente vel de proximo imminente, eo quod usum sibi necessarium habere potest sine dominio proprio. Aut hoc arguitur ex hoc, quia exponitur maiori indigentiae propter Deum, eo quod caret dominio proprio.'

51 De paupertate, p. 43: 'Ad hoc ergo quod aliquis sit vere pauper propter Deum, loquendo de paupertate ad propositum intelligo, quod ipse debeat ita diligere Deum, quod velit propter ipsum carere tribus: primo, quod velit carere tam dominio quam usu illarum rerum sine quibus vita alicuius congrue continuari potest; $2^{\circ}$ quod velit carere dominio rerum illarum sine quarum usu vita non potest continuari; $3^{\circ}$ quod velit carere usu superfluo rerum illarum sibi necessariarum ad sustentationem congruam vitae, scilicet tali usu, qui nec requiritur pro necessitate praesente, nec de proximo imminente secundum verisimile iudicium.' Cf. the more compressed version in Reportatio 3.16.1.15 (4:143).

${ }^{2}$ De paupertate, p. 43; but cf. p. 215: 'Sed fratres propter carentiam usus superflui et propter carentiam omnis dominii habent duplicem paupertatem. Unam enim paupertatem habent ex hoc, quod carent usu omnium rerum, quarum usu non indigent pro necessitate praesente vel de proximo imminente. Et aliam paupertatem habent respectu rerum, quarum habent usum et potestatem licite utendi; nam adhuc rerum illarum nec habent potestatem convertendi eas in quoscumque usus contra voluntatem dantis, nec potestatem eas defendendi seu vindicandi 
What, then, did lordship mean to Chatton? His concern was the everyday meaning of the word as friars would use it in their vow of poverty. Lordship in this sense covered three 'powers of doing things with the things necessary for use' $: 53$

D1. the power of converting those things as one pleases (indifferenter) to any use whatsoever against the will of another [e.g., the donor];

D2. the power of conserving [those things];54 and

D3. the power (when necessary) of defending them in court.

These three powers do not exhaust the range of things dominium might refer to. For example, the dominium the Church has reserved to itself of the goods the friars use consists of two different powers: ${ }^{55}$

CD1. the power of claiming things for the uses of the friars; and

CD2. the power of taking things away from the friars whenever it pleases.

Clearly, besides the obvious conceptual overlap between D1 and CD2 on the one hand and D3 and CD1 on the other, it is also apparent that friar who lacks D1-3 would be at the mercy of the person who is in possession of CD1-2.

There is a third 'modern' power Chatton felt compelled to mention. People sometimes say a lord of thing has: ${ }^{56}$

iudicialiter, nec potestatem eas conservandi ultra necessitatem, quae tres conditiones sunt conditiones dominii, sicut communiter sumitur.' Other references to the two categories of necessary and superfluous: De paupertate, pp. 47 and 54 .

53 De paupertate, pp. 43-4: 'Per dominium autem rerum necessariarum ad usum solet intelligi apud Religiosos potestas faciendi tria de illis rebus necessariis ad usum, scilicet: potestas convertendi illas res indifferenter in quoslibet usus contra voluntatem cuiuslibet alterius; et $2^{\circ}$ potestas conservandi; cum oportet, et ipsas iudicialiter defendendi.' Other references to dominium as this threefold power: De paupertate, pp. 54, 55, 213, 216, and 219.

54 Here the point is really one of conserving things 'ultra necessitatem praesentem et imminentem' ; see, e.g., De paupertate, p. 219.

55 De paupertate, p. 44: 'Sed quando curia Romana sibi reservat talis rei dominium, videtur aliter uti vocabulo dominii, scilicet pro potestate vindicandi res ad usus fratrum, vel pro potestate auferendi res illas a fratribus, cum sibi placuerit.' Cf. De paupertate, pp. 56 and 57; Reportatio 3.16.1.32 (4:149).

56 De paupertate, p. 44: 'Tertio modo videntur aliqui moderni temporis uti vocabulo dominii. Aliquando enim vocant dominum rei quemcumque habentem potestatem licite consumendi rem consumptibilem, et aliquando vocant dominum rei quemcumque habentem potestatem utendi re sine consumptione eius, et adhuc aliquando vocant dominum solum illum, cui sic debetur res ut nullus alius habeat potestatem licite utendi re illa.' Chatton subsequently clarified (De paupertate, p. 217) that this 'third' type of dominium could not be the sort that the Church reserved to itself, for it would be a 'simple and useless' dominium. 
$\mathrm{D}^{\prime} 1$. a power of licitly consuming a consumable thing;

D'2. a power of using a thing without consumption.

And, finally, a 'sole lord' is sometimes said to be,

$\mathrm{D}^{\prime}$ 3. he to whom a thing is owed in such a way that no other person has a power of licitly using that thing.

Chatton thus provided an intricate way of thinking about proprietary lordship (none of these powers would seem applicable to political lordship). What is perhaps most significant in this system is that these different ways of thinking about what dominium might mean are not mutually exclusive, although perhaps we should conclude that the lordship which the Church has reserved for itself seems to be a special subset of powers that does not apply in normal circumstances. Since Franciscan poverty is a unique form of poverty, this may not be overly surprising.

We can complicate the picture some given the close identification of dominium with potestas. Chatton admitted that Christ could have a 'human power of licitly ordaining, converting, distributing, and exchanging with respect to things necessary to them' and yet not have the three powers that Franciscans have renounced by vow (D1-3). ${ }^{57}$ The use of the words 'converting' and 'exchanging' seem clearly at odds with $\mathrm{D}_{1}$, but it is clear that he talking about administrative powers: that is, Christ qua prelate. These also seem to be powers that a dominus solus would have, or powers he could endow someone else with. Thus we should include them in Chatton's picture of proprietary lordship (collectively: $\mathrm{D}_{\mathrm{a}}$ ). In a way, this would seem to be a useful genus for the two powers that make up the Church's lordship over Franciscan goods, especially the second power (CD1-2).

With some rearranging, the picture of proprietary lordship for Chatton seems to look like Figure 1. Although it is clear that Chatton never combined everything into one overarching picture, we have not contradicted his theory if we describe the holder of dominium solum as being able to do D1-3 and $D^{\prime} 1-2$. That is, the lord of a thing, who can exclude others from using it, must himself be able to use it (which may entail consuming it), save it for later, or,

57 De paupertate, p. 53: 'Nec $3^{\circ}$ oportet hoc ponere ad salvandum quod ipse fuerit praelatus in disponendo et ordinando distributiones et commutationes victualium, se habens in hoc sicut magister et dominus; ut habetur, quod habuerit dominium secundum tres conditiones supradictas, quia simul stant, quod habuit potestatem humanam licite ordinandi, convertendi, distribuendi et commutandi respectu rerum eis necessariarum, et tamen quod nec voluit habere potestatem humanam ipsas vindicandi iudicialiter, nec conservandi ultra necessitatem praesentem vel de proximo imminentem, nec convertendi indifferenter in quoslibet usus contra voluntatem dantis.' 


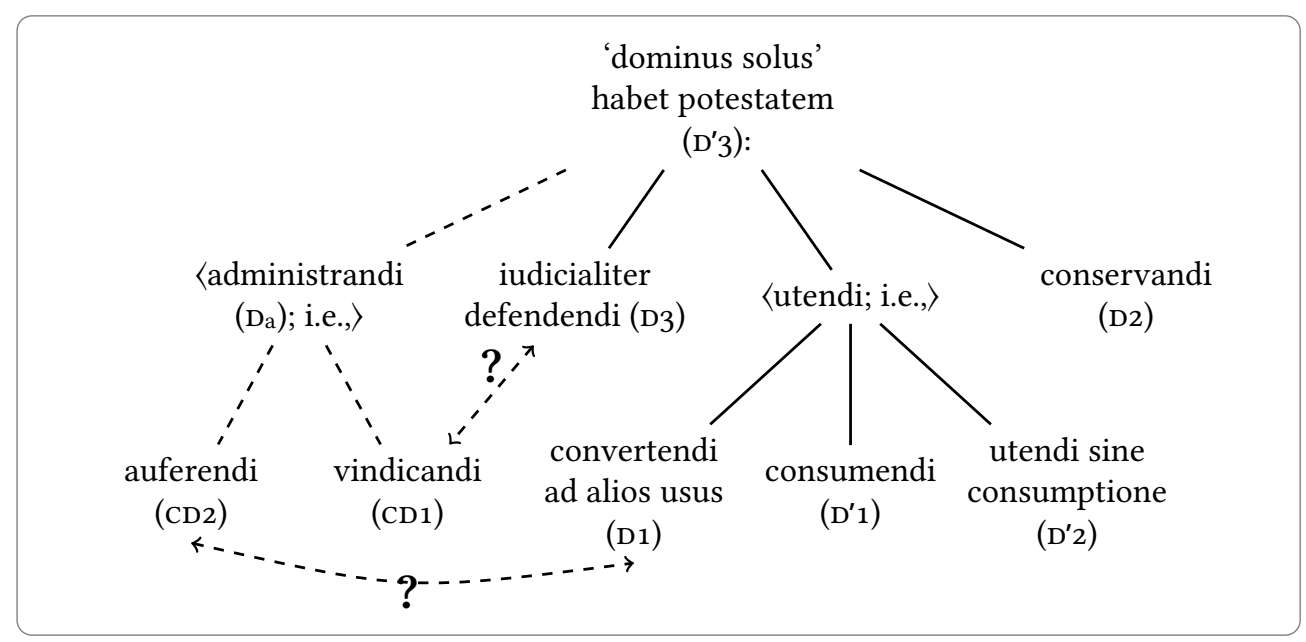

Figure 1: Walter Chatton and the powers of a dominus solus

presumably, convert it to another use; and if he 'can' exclude others from the use, then he must also be able to defend it in court. The dashed lines are more tenuous. A power to take away (CD2) sounds rather like the power of converting to other uses (D1), and in fact what I have named the power of administrating $\left(D_{a}\right)$ includes powers of converting and exchanging. The same must hold true for the powers of defending (D3) and claiming (CD1): what kind of claim does a vindicans have other than a juridical one? We should therefore be cautious of drawing lines of filiation as I have done here, but, as far as it goes, I believe it is a coherent picture.

Chatton was not interested in how these different powers can be rolled up into one, preferring instead to look at them individually, or in smaller groups in order to show how the Franciscans, individually and collectively, have voluntarily given most of these powers up. A point to note is that Chatton wrote that the presence of one power does not necessarily imply the presence of absence of another. ${ }^{5}$ This is not too different from modern accounts of ownership, which tend to speak of bundles of rights and duties while denying that ownership

$5^{8} \quad$ Reportatio 3.16.1.57 (4:155): 'Nec isti sensus inferunt primum, quia nulla habitudo est "iste licite consumit rem, igitur habet potestatem conservandi et augmentandi rem ultra necessitatem et iudicialiter vindicandi rem" etc. Ista enim distincta sunt, et potest quis privare se uno absque hoc quod privet se altero.' 
should be thought of as no more than a particular bundle of these rights and duties. ${ }^{59}$

It is no less important to note that the different meanings of dominium are always explained in terms of power (potestas). While Chatton is hesitant to talk about dominium and proprietas as (merely) the power to licitly consume a thing-for that would be to take the words in an unaccustomed way, more appropriate to a usuarius than dominus-he accepted that it could be stretched to such a use. ${ }^{60}$ We shall discuss the power to use in the next section, but for now, we need to consider the other three powers (D1-3).

Let us start with the power to conserve a thing for future use (D1). Chatton was well aware of the standard terminology, for he used the very phrases of the General Constitutions: 'present or imminent future necessity'. ${ }^{61}$ That is, he accepted that Franciscans must on occasion conserve hard to find items for the near future, and that this can be done without thereby acquiring property rights. The operative assumption was perhaps that present or future use by the friars would be the intention of the donor, who may nonetheless revoke the power to use at any moment.

What, then, is involved in the vow to lack lordship? What is being given up? According to Chatton, giving up lordship is not an example of privation of something (which was commonly understood as not being able to contribute to perfection), it is rather a positive act of the will. ${ }^{62}$ This is, for instance, what the Franciscans have done by depriving themselves of the power to take action in court. This instead was left to the Church (CD1). It was one power covered by the 'reservation of lordship', as Chatton called it. And unlike the rather negative way litigation was described by the Michaelists, Chatton saw it in a positive light. 'To litigate', he said, 'so that all injury is removed and justice observed, seems to be of perfection; in fact, it is of imperfection to omit this with respect to the one for whom this is licit. And by one's legal action, one can reduce

59 See, e.g., Tony Honoré, 'Ownership', Making Law Bind (Oxford, 1987), pp. 161-192, esp. pp. 183-4, and Jeremy Waldron, The Right to Private Property (Oxford, 1988), pp. 27-9, 46-53.

60 De paupertate, p. 219. Generally speaking, proprietas is not a word that has much of a role in Chatton's writings on poverty.

61 E.g., De paupertate, pp. 43, 49, 56, 215, 219; Reportatio 3.16.1.15-17, 22, 34-35, 41, 87,121 (4:143-4, 146, 149-50, 151, 161, 168). See Robinson, 'Property Rights', p. 160, for examples from different editions of the Constitutions, starting with those of Narbonne (1260). Unsurprisingly, given his role in the drafting of the Constitutions of Narbonne, Bonaventure, made a similar point in his Apologia pauperum 7.39, in Opera omnia edita studio et cura PP. Collegii a S. Bonaventura, 10 vols. (Quaracchi, 1882-1902), 8:285.

62 See p. 8, above. 
errors to right conduct'. ${ }^{63}$ In his elaboration of why this position makes sense, he conceded a small, but significant point. It is worth quoting in full:

I say for this reason that, on this point-that the Roman Curia would justly claim for the uses of the brothers, when it is necessary, things granted to them for necessary use-it suffices that the brothers themselves have a licence of using those things according to the will of the donor, for then those things would be owed to them for use in such a way that others could not take those things away from them (as far as use is concerned) without sin. But from this it does not follow that the brothers have any lordship over those things (just as 'lordship' includes the above-said conditions), nor that the brothers themselves may claim these things in court; not that the use of those necessary things is owed to the brothers in such a way that a claim cannot be just, but that the brothers have deprived themselves of the power of claiming things in court, just as is clear regarding Christ and the apostles. ${ }^{64}$

Chatton here denied the Franciscans dominium in some senses of the word, admitting only a licence of using, yet things are apparently owed to the friars in a way that results in it being wrong for others to interfere with the friars' use of the things in question, and that the Church can take legal action to recover them. One might wonder, as John XXII surely did, why this did not qualify as a 'right to use'. Chatton had claimed the use of ius utendi by the pope was more or less shorthand for dominium or proprietas, but there appears to be some inconsistency here. One solution, perhaps, would be to put the emphasis on the word necessary; it is, after all, always assumed by Chatton that we are talking about necessary, and not superfluous, use.

The last point is clearest where Chatton answers the objection that dominium could not be considered superfluous 'because, if the community cannot claim things or take possession of them in court, the use of everyone [in the

${ }_{63}$ De paupertate, p. 226: 'Quia litigare, ut tollatur omnis iniuria et iustitia observetur, perfectionis videtur esse; immo imperfectionis est hoc omittere ei, cui hoc est licitum. Et potest per eius actionem errata ad rectum reducere.'

${ }^{64}$ De paupertate, pp. 226-7: 'Ideo dico, quod ad hoc quod Curia Romana iuste vindicare pro usibus fratrum, cum oporteret, res eis concessas ad necesarium usum, sufficit, quod fratres ipsi habeant licentiam utendi rebus illis secundum voluntatem conferentis, quia tunc illae res ita eis deberentur ad usum, quod alii non possunt sine peccato res illas ab eis auferre quoad usum. Sed ex hoc non sequitur, quod fratres habeant aliquod dominium in rebus illis, prout dominium includit conditiones supradictas, nec quod ipsimet fratres possint res illas iudicialiter vindicare; non quin usus earum rerum necessariarum ita fratribus debeatur, ut vindicatio possit esse iusta, sed quod fratres privaverunt semetipsos potestate vindicandi res iudicialiter, sicut patet de Christo et Apostolis' (emphasis added). 
community] would depend completely on the free will [of others], and, consequently, when anyone can freely withdraw his favour at a moment's notice', the members of the community would expose themselves to peril, and could end up killing themselves through starvation. ${ }^{65}$ Among his responses to this objection, one was particularly germane in a post-Ad conditorem canonum world. According to Chatton, the lordship of the community was not needed for this since, if things needed for use are taken away undeservedly, although the friars cannot seek them in court, they can go to a prince or powerful man and beg for their help so that the necessary things are returned. ${ }^{66}$

Chatton's last line of defence for Franciscan poverty was that it was not strictly necessary that anyone have lordship of the goods the friars used. Chatton's account of corporate poverty is fairly straightforward, and anticipates the Michaelist position to a degree. ${ }^{67}$ For Chatton, a community is nothing more complicated than taking all the people of the community together. Thus, if all those people have 'one total lordship', and each person therefore has 'individual partial lordship', then if one lacks all individual partial lordship, he also lacks all lordship in common. ${ }^{68}$ Thus, a community can lack lordship just as easily as a person can. ${ }^{69}$ Chatton also made use of another argument that would become popular with Ockham, which was to point out that if all members of a

65 De paupertate, p. 50: 'Si dicatur, quod dominium communitatis non superfluit sed requiritur mediato, quia nisi communitas posset res iudicialiter vindicare et occupare, usus cuiuslibet illorum dependeret simpliciter ex libera voluntate et, per consequens, cum quilibet alius poterit libere suum beneficium subtrahere ad tempus, aliqua occasione accepta, quilibet illorum de illa communitate exponeret se ipsum discrimini et posset esse homicida sui, si moreretur fame.'

66 De paupertate, p. 52: '5 ${ }^{\circ}$ quia dominium communitatis non requiritur ad hoc, quod rehabeantur ablata indebite necessaria ad usum, quia si res necessariae concessae ad usum sunt ablatae, convenit eas repetere non iudicialiter sed mendicando, et contingit ire ad principem et divites, et mendicare ab eis auxilium eorum, ut tales res reddantur. Aeque enim contingit mendicare ab aliquo potente auxilium in casu necessario, sicut ab eo convenit mendicare victualia.' Cf. Reportatio 3.16.1.17 (4:144).

67 Tabarroni, Paupertas Christi, p. 95, noted the similarity to Ockham, but he was defending an earlier argument of Francis of Marchia; see Robinson, Ockham's Early Theory, pp. 275-81.

68 De paupertate, p. 49: ' 2 m assumptum patet ex articulo 2, nam habere dominium in communi est habere partiale dominium proprium, quia habere dominium in communi est communitatem habere dominium. Sed communitas non est nisi illae personae simul sumptae. Ergo hoc est illas personas simul habere unum totale dominium illius rei; et hoc est quamlibet personam esse partialem dominum et, per consequens, quaelibet persona habet dominium proprium partiale. Et sic si careat omni dominio partiali sibi proprio, careat omni dominio in communi.' Cf. De paupertate, p. 44; Reportatio 3.16.1.13 and 85 (4:143 and 161).

69

De paupertate, p. 48. 
community but one were to die out, whatever property rights that community had before would not magically devolve to the sole remaining individual. ${ }^{70}$

The purpose of Chatton's account of how corporations work was to be able to show that a papal retentio dominii, although done for pious reasons, was unnecessary. ${ }^{71}$ To help bring this point home, Chatton explained that when the Church had reserved to itself the lordship of the things granted to the brothers, one could understand this in three ways; however, the only correct way of understanding this reservation was in terms of the power of obtaining (or taking away) the things the friars use as it pleases (i.e., CD2)..$^{72}$ In this way, it was in fact entirely possible for the friars to lack lordship in the three key ways $(\mathrm{D} 1-3)$ and the Church to lack its form of lordship (CD1-2). ${ }^{73}$ It was possible, for example, for people to live by means of mendicancy (per viam mendicationis). ${ }^{74}$

On the one hand, Chatton's account is plausible in that he has carefully distinguished the different ways he believes the term dominium has been used. Yet, if neither the Church nor the friars have dominium of what the friars use, one might be inclined to think the things in question are res nullius and thereby available to the first person to take possession of them. Chatton was surely aware of the concept, though his terminology does not match that of the libri legales. ${ }^{75}$

70 De paupertate, pp. 52-3; Reportatio 3.16.1.18-19 (4:144-5). For Ockham, see OND 27.55-70 and 88.331-35 (OP 2:487, 661-2). See Robinson, Ockham's Early Theory, p. 163, and Miethke, Ockhams Weg, pp. 513-5. Chatton also suggested that the lordship of things in one case in the primitive Church remainined with the women who attended to the apostles from their own resources; see De paupertate, p. 233. A sign of the English connection can be seen in the reference to Grosseteste on the matter of apostolic corporate poverty: De paupertate, $\mathrm{p}$. 39 .

71 Cf. Damiata, Povertà e potere, 1:346; Douie, Heresy of the Fraticelli, p. 205; Miethke, Ockhams Weg, p. 389; and Tabarroni, Paupertas Christi, p. 97.

72 De paupertate, p. 213: 'Quantum ergo spectat ad istam deductionem notandum, quod Curiam Romanam reservare sibi dominium rerum concessarum fratribus potest tripliciter intelligi: uno modo, sumendo dominium pro potestate vindicandi res iudicialiter pro usibus fratrum [CD1], cum fuerit necessario, seu pro potestate assumendi res illas [one MS. reads: auferendi res illas ab eis, vel assumendi sibi ad usum] cum sibi placuerit; et altero istorum modorum Curia reservat sibi dominium illarum rerum. [L]icet observantia status fratrum hoc non requirat.' The second way refers to the licit power of using $\left(=D^{\prime} 1-2\right)$, while the third refers to $\mathrm{D} 1-3$.

73 De paupertate, p. 228: 'Simul enim stant, quod fratres ipsi non habeant illam triplicem potestatem supradictam, nec etiam quod Curia Romana eas possit vindicare vel auferre.' Cf. De paupertate, pp. 214, 220, 221, 225, 226.

74 De paupertate, p. 228.

75 De paupertate, p. 56: 'quia, si rerum quarum Christus, - et arguo - vel etiam fratres Minores habuerunt usum, nullus dominium haberet, tunc illarum dominium sub incerto poneretur 
Chatton's response depended on his position regarding corporate lordship. If everyone in the world were to die besides one good Franciscan-or one of the apostles, or Christ-the state he could observe would not be effected: although no one else would have human lordship, neither would the sole survivor. ${ }^{76}$ The implicit assumption was most likely that Chatton thought that one cannot hold property without the will to do so, which would rule out children and madmen, as well as people who have vowed to live without property. ${ }^{77}$ This was a common belief, ${ }^{78}$ and it would mesh well with his belief that a vow of poverty, or the desire to be poor, precluded the possibility of acquiring property, ${ }^{79}$ and with his point that wishing to lack lordship is a positive act of the will. ${ }^{80}$ In fact, a vow of not having lordship and its observance does not require that another have the lordship. ${ }^{81}$

et occupanti concederetur.' Cf. Inst. 2.1.12 (1:1:11): 'quod enim ante nullius est, id naturali ratione occupanti conceditur' (= Dig. 41.1.3 pr. [1:1:69o]); and Glos. ord. ad D. 1 c. 7, s.v. 'capiuntur', in Gratian, Decretum Gratiani. mit der Glossa ordinaria von Johannes Teutonicus in der Bearbeitung von Bartholomaeus Brixiensis (Mainz, 1472): 'Haec enim et alia quae in nullius bonis sunt, ceduntur ocupanti: ut insti. de rerum di. §. fere 〈Inst. 2.1.12〉.' References to Roman law are taken from Paulus Krueger et al., eds., Corpus iuris civilis, 3 vols. (Dublin, 1966).

${ }^{76}$ De paupertate, p. 56: 'Statum enim illum Christus, vel unus Apostolus, vel bonus frater Minor potuit servasse, si omnes homines mundi praeter ipsum essent mortui, et tamen tunc nullus alius ab eo haberet dominium humanum respectu totius mundi.'

77 See Douie, 'Three Treatises', p. 353, who cited Plut. 31 sin. 3, fol. 184vb, from the question Utrum professio qua cuilibet rei renuntiatur tam in proprio quam communi, sit perfectior et magis meritoria, ceteris paribus, quam illa qua renuntiatur in proprio tantum. The authorship of this question remains uncertain; Douie followed the opinion of Fr Heysse, who thought the author of this question was the same as that of question Douie subsequently edited in her article. See Albanus Heysse, 'Descriptio Codicis Bibliothecae laurentianae Florentinae S. Crucis, Plut. 31 sin., Cod. 3', Ar-chi-vum franciscanum historicum, XI (1918), pp. 251-269, pp. $252-3$.

78 Michael of Cesena and his fellow dissidents, for example, held similar views. See Appellatio maior, ed. Gál and Flood (above, n. 13), pp. 251-2, and OND 41.66-72 (OP 2:524).

79 See, e.g., De paupertate, pp. 37 and 42; Reportatio 3.16.1.12-14, 21 (4:142-3, 145). On Christ and the apostles, De paupertate, pp. 38 and 55; Reportatio 3.16.1.19 (4:145).

80 See p. 8 , above.

81 De paupertate, p. 53: '3 $3^{\circ}$, quia vovens carere omni dominio propter Deum, non vovet, quod alius habebit dominium, sed quod ipse non habebit dominium. Ergo obsersantia sui voti non requirit, quod alius habeat dominium.' 


\section{Chatton on usus}

Chatton spoke about dominium in terms of potestas; since he spoke about usus in the same terms, it remains to examine where and why use and lordship differ, if at all. As the earlier diagram tries to show, dominium-if that is what a dominus solus should be said to have-often includes various powers of using as part of its feature set.

Yet Chatton took it as self-evident that lordship and use had to be separable because otherwise 'every religious in the world would have direct (immediatum), total lordship of the thing that he consumes, and thus lordship individually' ${ }^{82}$ Where Chatton and the pope seemed to agree was on the point that the friars cannot be considered to be 'only users' (tantum usuarii). The 'kind' of dominium Chatton meant in this case was that of taking dominium for the power of licitly consuming a thing. This passage also deserves to be quoted in full:

This deduction seems to proceed with respect to lordship and ownership not [taken] according to the customary understanding, according to which those religious vow to lack lordship, but by taking lordship for a power of licitly consuming a thing; for, by taking lordship in this way, and proportionally taking usage (usuarium) in this way-by distinguishing it from having a power of licitly consuming such a thing-the deduction holds up well. For they are not such users only: rather, they have a power of licitly consuming a thing [D'1] according to the will of the donor. Yet, with this it stands that they are users in this way: that they neither have the power of converting things [D1] to any use they wish against the will of the donor, nor the power of claiming those things in court [D3], nor the power of conserving them beyond present and imminent future necessity [D2]. And therefore, by taking lordship for the lordship that includes that triple power [D1-3] with respect to those things which are consumed by use, they thus have no lordship, but are only users (distinguishing usage from having such lordship). ${ }^{83}$

82 De paupertate, p. 220: 'Si tunc talis usus non separetur a dominio, quilibet religiosus in mundo haberet totale dominium immediatum illius rei quam consumit et sic dominium in proprio.' See also Reportatio 3.16.1.56 (4:155); and cf. De paupertate, p. 221 . As is well known, while other Franciscans could and would agree with this reductio ad absurdum, Pope John XXII seemed to endorse the very idea Chatton found so preposterous.

${ }_{3}$ De paupertate, p. 219: 'Ista deductio videtur procedere de dominio et proprietate non ad intellectum consuetum, ad quem religiosi illi vovent carere dominio, sed sumendo dominium pro potestate licite consumendi rem; sic enim sumendo dominium et sic proportionaliter sumendo usuarium, distinguendo ipsum contra habentem potestatem licite consumendi rem talem, bene tenet deductio. Non enim sunt tales usuarii tantum, quin habeant potestatem 
The reason the 'users' in this quotation have a power of consuming rather than a more generic power of using is explained by the fact that Chatton was writing in the context of using consumables. We know, however, that he thought the basic mechanics of using consumables and non-consumables were the same. ${ }^{84}$

The key to all of this are the terms potestas and licite. Chatton agreed with the pope that one cannot 'give' an act of using to another. In the case of one person letting another ride his horse, Chatton repeated that the donor gives neither the horse, nor the act of riding; rather, he grants that the other person 'can exercise his act of riding'. That is, he grants him a ius utendi. ${ }^{85}$ Chatton, we know, mostly avoided speaking in terms of the right of using; he also avoided speaking about use of fact, though there is some slight evidence that he thought usus facti and usus simplex were interchangeable. ${ }^{86}$ For him, the issue was whether one was acting (or obligated to act) according to the will of the donor. What the donor must give them is the potestas, that is, the authority to use the thing licitly: 'If, therefore, lordship is taken for the potestas of consuming a thing licite, and the one conferring [it] reserves to himself that lordship, by meaning lordship in this way, they cannot then consume the thing licite ${ }^{3}{ }^{87}$ In other words, the dominus must give the power: it is not innate, and there is no mention in this case of the licence of using (licentia utendi), which the Michaelists would rely on so heavily.

licite consumendi rem secundum voluntatem dantis. Cum isto tamen stat, quod sic sunt usuarii, quod nec habeant potestatem convertendi res in quoslibet usus contra voluntatem dantis, nec potestatem licite vindicandi res illas iudicialiter, nec potestatem conservandi eas ultra necessitatem praesentem et imminentem. Et ideo, sumendo dominium pro dominio includente istam triplicem potestatem respectu istarum rerum quae usu consumuntur, sic nullum dominium habent sed sunt usuarii tantum, distinguendo usuarium contra habentem tale dominium.'

84 Reportatio 3.16.1.42 (4:152): 'Nam renuntiatio talis dominii, scilicet quae excludat licitam potestatem utendi et consumendi rem, vel in casu utendi sine consumptione, non faceret ad perfectionem.' De paupertate, p. 226: 'Certum est enim, quod habuerunt potestatem licite utendi rebus eis necessariis ab aliis collatis, et tamen eis fuit prohibitum aliquod vindicandi iudicialiter.' Cf. De paupertate, p. 228.

85 De paupertate, p. 222: 'Verbi gratia, accommodans alteri equum, non dat ei equum, nec dat ei actum equitandi, quia ille actus equitandi non est suus, sed concedit sibi quod suum actum equitandi possit exercere in equo suo; hoc enim est concedere sibi ius utendi.' Cf. $A C C^{2} 158-167(242-3)$.

87 De paupertate, pp. 222-3: 'Si ergo dominium sumatur pro potestate licite consumendi rem, et conferens sibi ipsi reservet illud dominium, sic volendo dominium, tunc non possunt licite consumere rem.' 
Thus, whereas John XXII spoke about the right of using, and the Michaelists about the licence of using, Chatton framed his answer in terms of a power of using; in the Reportatio, he once wrote about a 'licit power of using' (de licita potestate utendi), which is perhaps closer to the Michaelist positions. ${ }^{88}$ Yet, Chatton was also content to admit that this power of using was the same as the pope's meaning of ius utendi, although he did insist that this use of 'right of using' was not the one used when friars abdicated a ius utendi in their vow. ${ }^{89}$ (This may seem somewhat surprising since the Rule never once mentions a right of using; nor, in fact, do any of the General Constitutions.)

All this talk of a power of using licitly should make another thing clear: the use must, quite literally, be allowed in some way..$^{\circ}$ In the first place, only the use of necessary things was allowed. All superfluous use is out, which includes everything beyond what is presently necessary or necessary in the imminent future. For Chatton, that included food, clothing, the divine office, and sapiential study. ${ }^{91}$ The other important criterion was that the use was done according to the wishes of the donor. This seems to be the main point of the power of converting (D1). Lacking the power to convert things to other uses against the wishes of the donor carefully circumscribes the 'power' the friars have. Franciscans might have a power to use non-superfluous things necessary for life, study, and spiritual duties, but that is all they had. Moreover, the friars could neither use goods against the wishes of the donor, nor without the sanction of the Church. Although there is not a hint of the controversial usus pauper terminology, Chatton envisaged an austere modus vivendi, albeit one replete with a qualified form of potestas.

\section{Conclusion}

One conspicuous difference between Chatton and most other contemporary defenders of Franciscan poverty is the almost complete absence of ius naturale. One might be inclined to see this as a development stemming from the Scotist account of the development of private property. Like Chatton, John Duns Scotus

$88 \quad$ Reportatio 3.16.1.69 (4:158); cf. Reportatio 3.16.1.46 (4:153): 'licitam potestatem commutandi res huiusmodi et licite utendi et consumendi.' See further Robinson, Ockham's Early Theory, 184-9, 201-4, and 215-7.

89 De paupertate, p. 225.

90 De paupertate, p. 224, spoke briefly of usus licitus, but not in a way helpful to the point presently being considered.

91 De paupertate, p. 50; Reportatio 3.16.1.15 (4:143). 
(1265/66-1308), writing in the first decade of the fourteenth century, also seemed to disregard the juristic propensity to distinguish between lex and ius, and to elaborate a theory of the origins of dominium based entirely on human positive law..$^{92}$ Yet, while other authors tended to discuss ius and the case of extreme necessity, Scotus included, ${ }^{93}$ Chatton did not. Property for Chatton was a feature of regular positive law, and his account of it gave ample scope for Franciscan non-ownership without recourse to suprahuman systems of law (ius), either positive or non-positive. Yet although the friars managed to do without direct ownership, and although what they used was meant to be limited to the austere category of the non-superfluous use of necessities, Chatton set high standards for the respect of property rights. Medieval authors tended to treat property rights as largely immune from outside interference, ${ }^{94}$ but Franciscan non-ownership turned the question from a bilateral concern with an onwer / non-owner dynamic into a three-party arrangement composed of an

92 See Ordinatio 4, dist. 15, q. 2, art. 1, in Allan B. Wolter, ed. and trans., fohn Duns Scotus: Political and Economic Philosophy (St. Bonaventure, NY, 2001), pp. 28-34, which, in addition to arguing for a positive law origin of dominium, also shows Scotus reformulating Augustine's distinction (in D. 8 c. 1) between human and divine ius, and a paraphrase of the res nullius doctrine in the Institutes (2.1.12), which speaks of naturalis ratio, in terms of lex naturae or positiva. See Roberto Lambertini, La povertà pensata: Evoluzione storica della definizione dell'-identità da Bonaventura ad Ockham, Collana di storia medievale 1 (Modena, 200o), pp. 113-21; Luca Parisoli, La Philosophie normative de fean Duns Scot: Droit et politique du droit, Bibliotheca Seraphico-Capuccina 63 (Rome, 2001), pp. 125-37; and Allan B. Wolter, trans. and introd., Duns Scotus on the Will and Morality. Translation edition edited by William A. Frank (Washington, DC, 1997), pp. 73-5. Wolter, ed., trans., Scotus: Political and Economic Philosophy, pp. 76-8.

94 See Joseph P. Canning, 'Italian Juristic Thought and the Realities of Power in the Fourteenth Century', in Political Thought and the Realities of Power in the Middle Ages / Politisches Denken und die Wirklichkeit der Macht im Mittelalter, ed. Joseph Canning and Otto Gerhard Oexle (Göttingen, 1998), pp. 229-239, for a similar opinio communis among contemporary jurists. One area that deserves further study is what rights owners really have to superfluous goods. Fr Ermenegildo Lio has worked extensively on the Franciscan tradition in this regard; see especially his editions of Alexander of Hales and Bonaventure: Ermenegildo Lio, ed.Determinatio 'superflui' in doctrina Alexandri Halensis eiusque scholae, Spicilegium Pontificii Athenaei Antoniani 6 (Rome, 1953), and Ermenegildo Lio, ed.S. Bonaventura e la questione autografa 'De superfluo' contenuta nel MS. di Assisi, Bibl. Comun. 186 citata al concilio Vat. 11. Testo con studio critico-letterario e dottrinale (Rome, 1966). Brian Tierney, Medieval Poor Law: A Sketch of Canonical Theory and its Application in England (Berkeley, 1959), p. 146 n. 23, lists his other articles. Dominicans, too, thought about this problem; see Janet Coleman, 'Property and Poverty', in The Cambridge History of Medieval Political Thought, c. 350-c. 1450 , ed. J. H. Burns (Cambridge, 2005), pp. 607-648, pp. 623-5, for a brief discussion of Aquinas's views. 
owner, a user, and an outside party. According to Chatton, the obligations of non-interference by the outside party are owed to the owner, not the user; and it is all tied to the belief that the owner's will about how his or her goods may be used must be respected. Respect for the owner's wishes also explains the limited potestas a friar has when he uses a thing he does not own. Had Chatton wanted to, he could have pointed to the Franciscan Rule, which stated that the friars were to eat from whatever was set before them, as an example of living according to the wishes of another. ${ }^{95}$ That is, the friars, like traditional monks, do not get to decide for themselves how and what they are supposed to do with the things given to them. ${ }^{96}$

Although it is unsurprising that a friar (or a monk) should not act according to his own will from the perspective of the goal of religious life, it is hard to reconcile with medieval moral philosophy or indeed with the history of the poverty controversy. ${ }^{97}$ Regarding the poverty controversy, the so-called Spirituals time and again took it upon themselves to judge whether the order (and its leadership especially) was operating according to the Rule and true intentions, as they understood them, of their founder. Official bulls, including the recent Exivi de paradiso (1313) and Quorundam exigit (1317) were unable to convince the disaffected that obedience to their superiors would be enough to ensure they were fulfilling their vow of poverty. ${ }^{98}$ The philosophical problem is no less significant. As noted above, Chatton placed important cognitive demands on the determination of right conduct. And yet, his explanation of Franciscan poverty explained that a friar exercises no judgment of if, how, or when he may use the things he does not own. In such a scenario, it is not clear how his actions could be considered meritorious. (Incidentally, a similar problem existed for the Michaelist solution based on the licence to use, and yet none of the Michaelists, Ockham included, addressed the conflicting requirements of

95 Francis of Assisi, Regula bullata 3.14, in Cajetan Esser, ed., Opuscula sancti patris Francisci Assisiensis (Grottaferrata, 1978), p. 230: 'Et secundum sanctum Evangelium de omnibus cibis, qui apponuntur eis, liceat manducare' [cf. Lc. 10:8].

96 Cf. Regula S. Benedicti 5.10-13 and 33.1-4, in Timothy Fry, ed., RB 1980: The Rule of St. Benedict in Latin and English with Notes (Collegeville, MN, 1981), pp. 188 and 230. See Robinson, Ockham's Early Theory, p. 136, for further discussion.

97 See, however, Mary Beth Ingham, 'Self-Mastery and Rational Freedom: Duns Scotus's Contribution to the Usus pauper Debate', Franciscan Studies, LXVI (2008), pp. 337-369, who recently suggested that Peter of John Olivi's writings on usus pauper and the will's self-mastery might help us understand Scotus's understanding of the freedom of the will.

98 David Burr, The Spiritual Franciscans: From Protest to Persecution in the Century After Saint Francis (Philadelphia, 2001), pp. 161-70; Robinson, Ockham's Early Theory, pp. 30-2. 
the lack of individually-determined ability to use based on externally granted licences, the vowed(!) duties to obey one's religious superiors, and the cognitive requirements for ethically correct action.)

Chatton's account is unlikely to have found support from all corners of his order, however. The biggest hurdle is where he wrote that friars may beg the pope or a secular lord extra-judicially so that the goods the friars use-or are supposed to use-might be restored to them. This kind of arrangement may well make sense for an international religious order tens of thousands strong, but it probably gave the friars too much control to appeal to friars inclined to more austere forms of evangelical poverty. To a critic like Ubertino da Casale, for instance, appealing to the pope for the restoration of goods might smack too much of wearing gloves in order to avoid handing money directly. ${ }^{99}$

The most remarkable feature of Chatton's interpretation of Franciscan poverty is the avoidance of any significant discussion of 'rights' in the senses we have come to expect from the texts of this period. In discussing the forever contested ius utendi, however, Chatton concluded that an owner is granting a power to use, and the point is that a person who receives this potestas has received legitimate authority to use the thing. In admitting that this could be what the pope meant by the term 'right of using', it may seem that Chatton was willing to admit Franciscans have a right to the things they use; but it should be clear that Chatton did not think this was a 'right' in the relevant sense because Franciscans do not have any control over how a thing is to be used, or even if it can be used should the owner decide otherwise. What mattered most to Chatton's conception of poverty was that friars gained only the authority to use in accordance with the owner's wishes. It is a carefully circumscribed power, and it underscores that for a medieval author even the language of power need not imply that a person is operating in the realm of unfettered power relations disentangled from the bonds of morality or the demands of society.

Other aspects of ownership as described by Chatton do suggest that his list of the 'incidents of ownership' (to use Honoré's terminology) include an

99 E.g., his comment in the text known as Rotulus iste in relation to the passage in the Rule (4.1) that the brothers not receive money, in Franz Ehrle, 'Zur Vorgeschichte des Concils von Vienne', in Archiv für Literatur- und Kirchen-geschichte des Mittelalters, ed. Henrich Denifle and Franz Ehrle, 7 vols. (Graz, 1885-1900), 2:353-416, 3:1-195, p. 106: 'Et in huiusmodi transgressione mandati de pecunia prelati et subditi, senes et iuvenes sic sunt relaxati, quod de non recipiendo pecuniam solo videmur nomine, ex eo quod non tangimus manibus, gloriari.' Ubertino was defending an earlier statement made in Sanctitas vestra (ibid., p. 67) to the same effect. See Burr, Spiritual Franciscans, pp. 125-6, for context. 
autonomous sphere of choice, as one would expect. The decision to describe all these incidents in the language of potestas brings everything into sharper focus. Although these are powers no Franciscan (qua Franciscan) possesses, they seem to be powers that belong to the realm of free choice insofar as they are described by Chatton as powers to convert or conserve property according to one's wishes. This differs in some respects from the more duty-bound role earlier scholastic authors envisioned for property in both the Franciscan and Dominican camps. ${ }^{100}$ Be that as it may, it should be clear by now that Chatton's contribution to the question of Franciscan poverty, while undoubtedly a Franciscan contribution, was distinctly his own, and it helps us see how broad the 'Franciscan' spectrum was when it came to property and poverty. It is often remarked that for an order of friars who wished to do without (positive law-based) rights, they spent a lot of time worrying about rights of all sorts. Chatton is evidence that a sophisticated theory of poverty need not be based on such language.

100 Cf. Virpi Mäkinen, 'The Influence of the Commentaries on Aristotle's Nichomachean Ethics and Politics on the Discussion on Property Rights', Documenti e studi sulla tradizione filosofica medievale, XVII (2006), pp. 283-298, pp. 288 and 298. Janet Colman has published several studies recently that aims to be sensitive to the differences between the Franciscan, Dominican, and Augustinian traditions on the one hand, and the deontological nature of medieval theories of 'rights' on the other; see especially: 'Pre-Modern Property and SelfOwnership before and after Locke', European fournal of Political Theory, IV.2 (2005), pp. 125145; 'Are There Any Individual Rights or Only Duties?', in Transformations in Medieval and Early-Modern Rights Discourse, ed. Virpi Mäkinen and Petter Korkman, The new synthese historical library 59 (Dordrecht, 2006), pp. 3-36; and her 'Using, Not Owning'. 